Planning the British Economy 


\title{
Planning the British Economy
}

\author{
PAUL HARE
}

Economics Department

University of Stirling 
ISBN 978-0-333-36111-5 ISBN 978-1-349-18033-2 (eBook)

DOI 10.1007/978-1-349-18033-2

๑P. G. Hare 1985

Softcover reprint of the hardcover 1st edition 1985

All rights reserved. For information, write:

St. Martin's Press, Inc., 175 Fif th Avenue, New York, NY 10010

First published in the United States of America in 1985

ISBN 978-0-312-61427-0

Library of Congress Cataloging in Publication Data

Hare, P. G.

Planning the British economy.

Bibliography: $p$.

Includes index.

1. Great Britain-Economic policy-1945-

I. Title.

$\begin{array}{llll}\text { HC256.6.H347 } & 1985 & 338.941 & 85-14291\end{array}$ 
To Sue, Kathryn and Cheryl 


\section{Contents}

List of Tables and Figures ix

Preface $\quad$ x

1 Introduction 1

1.1 Planning and markets 3

1.2 Education and manpower planning 11

$\begin{array}{lll}1.3 & \text { Statistical material } & 17\end{array}$

2 British Experience 23

2.1 Wartime planning 23

2.2 The National Plan 31

2.3 The Labour Government, 1974-9 45

2.4 Planning at the level of the firm 64

$\begin{array}{ll}2.5 & \text { Lessons from the past }\end{array}$

3 Planning in Other Countries 73

3.1 Eastern Europe: debates on economic reform 74

3.2 France $\quad 88$

$\begin{array}{llr}3.3 & \text { Japan } & 96\end{array}$

3.4 Some lessons for Britain 110

4 Theoretical Approaches 114

4.1 Indicative planning 115

4.2 The allocation of investment 126

4.3 Planning and macroeconomic policy 139

4.4 Decomposition of planning 145 


\section{viii Contents}

5 Planning and Democracy 151

5.1 Workplace democracy 151

5.2 Local, regional and national plans 165

5.3 Democratic planning 131

6 Institutions: Developing the Existing Structure 185

6.1 The rôle of nationalised industries 186

6.2 The financial institutions 194

6.3 Enterprise boards and development agencies 203

6.4 Regulation of international transactions 208

7 Institutions: Proposals for Change 221

7.1 National level planning institutions 222

7.2 Lower level institutions 240

7.3 Regulation of prices and wages 244

8 Conclusions 256

8.1 Decentralised, market-oriented planning 257

8.2 The alternative economic strategy 259

8.3 Planning in other developed countries 264

$\begin{array}{ll}\text { References } & 268\end{array}$

$\begin{array}{ll}\text { Index } & 280\end{array}$ 


\section{List of Tables and Figures}

\section{Tables}

1.1 Output and investment in the UK 18

1.2 Gross and net capital formation and GDP by sector 18

1.3 Net fixed capital formation by industry group 20

1.4 Capital-output ratios by industry group 21

1.5 Investment ratios: international comparisons 22

2.1 Stop-go policies up to the early 1960s 32

2.2 Incomes policy, 1975-9 60

6.1 The financial institutions 194

8.1 Variants of the Alternative Economic Strategy 260

\section{Figures}

1.1 Price-type planning procedure 8

2.1 A typical budget $\quad 26$

4.1 Economic life of alternative investments 135

4.2 Outline structure of proposed planning system 149

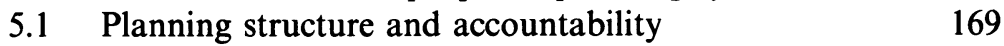

7.1 Co-ordination of nationalised industry and other public sector investment 225

7.2 Decentralising the implementation of investment plans 230

7.3 Planning within the government structure 235 


\section{Preface}

As an economist with a long-standing research interest in the planned economies of Eastern Europe, as well as China, it was probably inevitable that I would eventually turn my attention to the prospects for planning in my own country, Britain. At first sight, the prospects seemed rather dim and any story that one might tell about planning in Britain would therefore be quite brief. However, more careful reflection suggested that there was actually a great deal to say, and that some form of planning could make a significant positive contribution to improving Britain's economic performance.

Of course, there could be no question of importing wholesale the methods and institutional arrangements of economic planning from some other country. However, by investigating the strengths and weaknesses of planning systems in several countries, including some market-type economies where alternative forms of decentralised planning are employed principally to guide the allocation of investment resources, we can draw some useful conclusions about lessons for Britain. Similarly, Britain's own past experience of planning, as well as a range of theoretical arguments to do with economic information and the rate and pattern of investment, all have implications for the kind of planning system that would suit British conditions. These implications then require sufficient elaboration to show how the proposed form of decentralised economic planning would fit into the existing institutional structure, and what new institutions it would entail.

These issues are all discussed thoroughly in what follows, including a specific set of proposals for British planning and some comparisons with other recent proposals such as the 
Alternative Economic Strategy. In setting out my argument, I felt that many points could be explained more clearly in the context of some concrete suggestions, but some aspects of my proposals should nevertheless be regarded as quite tentative and preliminary rather than as a blueprint for immediate action. Thus in some respects I see this book as a contribution to a debate about the future shape of economic policy in Britain, and therefore welcome other contributions, including further development of the ideas presented here.

In a work of this kind the author cannot make progress without the support and co-operation of numerous colleagues. My own greatest debts are to some of my academic colleagues who commented on one or more chapters and took part in discussions about various parts of my argument and proposals. I would particularly like to thank Athar Hussain, Saul Estrin, David Simpson, David Ulph and Neil Fraser. In addition, I am grateful to Labour Party and TUC officials for giving up their time to assist me, both by ensuring that I was fully informed about their respective organisations' official positions, and by commenting constructively on my own views; Henry Neuberger (Labour Party) was especially helpful in this regard. Wherever possible I have tried to take account of critical comments advanced by the above individuals, and a few others. However, none of the above can be held responsible for any of the views set out below; indeed in some cases $\mathrm{I}$ am all too aware that significant areas of disagreement remain between myself and some of the above commentators.

Unlike some research projects, this one did not require large resources. In order to hold meetings with various officials and academics, however, it was necessary to travel down to London quite frequently, and I am grateful to the Carnegie Trust for providing the necessary financial support. In addition, Ann Cowie and Catherine McIntosh managed to transform my handwriting into an impressively neat and clear typescript in a remarkably short time; I can hardly thank them enough for their efforts and for their patience in accommodating my frequent amendments and revisions.

Finally, I would like to thank my wife and daughters for their contribution to this book: my wife for tolerating far too many unsociable weekends while I was busy writing; and my daughters 
xii Preface

for keeping out of my way when required and for providing pleasant and often entertaining company when I needed to relax.

I hope that in 1985 I shall have more time for the family than I had in 1984.

Economics Department

Paul Hare

University of Stirling

Scotland

January 1985 